\title{
Genetic-Epidemiological Studies in Progressive Muscular Dystrophy*
}

\author{
JANINA PROT \\ From the Department of Neurology, Medical School, Warsaw, Poland
}

A genetic and epidemiological study is especially important in those hereditary diseases for which no effective treatment is known, since then genetic counselling is the only means of prevention. The progressive muscular dystrophies are typical conditions of this sort. Knowledge of the type of hereditary transmission for a given form of muscular dystrophy is the basis for correct genetic prognosis. Finding methods of detection of gene carriers is crucial for genetic counselling.

Estimation of such parameters as relative fitness, mutation rate, incidence, and prevalance types of progressive muscular dystrophy is important not only from a purely academic point of view but also from a practical one as well. It is important for accurate planning of services such as rehabilitation centres, hostels for crippled children, hospital and sanatorium beds. For this reason we undertook a genetic and epidemiological study of muscular disease in Poland.

\section{Patients Classified by Type of Progressive Muscular Dystrophy}

The patients were those treated in the Neurological Department of Warsaw School of Medicine in 19531968; their relatives were examined in the Department's Dispensary for Muscular Disease. The total of patients under observation, in whom progressive muscular dystrophy was diagnosed by neurological examination and laboratory investigations (electromyography, muscle biopsy, and serum creatine kinase and aldolase activity), was 380. They came from 296 families. Their distribution by type of dystrophy diagnosed and number of families is given in Table I.

\section{Results}

Duchenne's progressive muscular dystrophy. The 215 patients came from 178 families. There were 183 propositi and 32 secondary cases. Detailed family histories were collected in 167 cases.

Received 19 June 1970.

* Study supported by N.I.H., N.I.N.D.B. (agreement 227702).
TABLE I

\begin{tabular}{l|c|c|c|c}
\hline & \multicolumn{2}{|c|}{ Type of Progressive Muscular } & \multirow{2}{*}{ Dystrophy } \\
\cline { 2 - 3 } & Duchenne & $\begin{array}{c}\text { Limb } \\
\text { Girdle }\end{array}$ & $\begin{array}{c}\text { Facio- } \\
\text { scapulo- } \\
\text { humeral }\end{array}$ & \\
\hline No. of patients & $\begin{array}{c}215 \\
(56.6 \%) \\
178\end{array}$ & $\begin{array}{c}136 \\
(35.7 \%) \\
104\end{array}$ & $\begin{array}{c}29 \\
(7 \cdot 7 \%) \\
12\end{array}$ & $\begin{array}{c}380 \\
(100 \%) \\
(4.1 \%)\end{array}$ \\
No. of families & $(60.6 \%)$ & $(100 \%)$ \\
\hline
\end{tabular}

The analysis of pedigrees suggested recessive sexlinked inheritance in 18 families $(10.8 \%)$; in 18 families more than one boy in the sibship was affected $(10.8 \%)$, and in the remaining 131 families $(78.4 \%)$ the patients represented isolated cases. There are no detailed data on 11 families, and in 22 families the patient was the only child. In the remaining 156, there were 193 patients and 343 unaffected sibs, 167 of them male and 176 female. None of our patients had any offspring-the coefficient of relative fitness was zero.

The frequency of mutations was estimated by the indirect method after Haldane (1935). The assumption was made that registration covered all patients born between 1953 and 1960 in the city and voivodeship of Warsaw.

The direct method, according to the formula, $u=\frac{1}{3}-(1-f) \times x$; since the relative fitness $f=0$, $u=\frac{1}{3} \times x, x$ being the birth ratio of affected boys to normal boys. In 1953 to 1960 we observed 46 patients from 42 families according to the data of the Polish Statistical Bureau 328,110 boys were born during these years in the area in question and thus

$$
x=\frac{46}{328,110}=0 \cdot 000140=14 \cdot 10^{-5}
$$

and

$$
u=\frac{1}{3} \times 0.000140=0.000046=46 \cdot 10^{-6}
$$

per gene per generation. 
Assuming complete registration of cases in the city and voivodeship of Warsaw, we calculated the incidence rate and prevalence of Duchenne's dystrophy. According to our data the former was 140 per million (in particular years, the figure varies from 80 to 220 affected boys in one million births of boys), and the prevalence was 19.5 in one million of the male population.

Benign X-linked progressive muscular dystrophy, i.e. Becker's form (1962). In genetic and epidemiological respects we considered only two families, in which the diagnosis occasioned no doubts. We had 10 patients under observation, 7 of whom were 25 years or more. Five of the latter were married, and 4 of the 5 had jointly 11 children. The relative fitness of the patients was reduced. The average number of children was 1.57 for the patients, and 2.25 for their unaffected sibs aged upwards of 25 years. The relative fitness was therefore $1 \cdot 57: 2 \cdot 25=0 \cdot 70$, and thus even slightly better than in our material of limb girdle progressive muscular dystrophy.

The material was too scant for calculations of the rates of mutation incidence, or prevalence. Presumably, the mutation rate is low and the disease rare; in our material we observed in two families indubitable Becker's form of progressive muscular dystrophy, and in two families the disease was doubtful, whereas the typical acute form of Duchenne was observed in 178 families. But it needs to be borne in mind that isolated cases of the benign form probably are often diagnosed as limb girdle dystrophy. A reliable method for differentiation between the two forms would be most important for the genetic prognosis.

Limb girdle progressive muscular dystrophy. The 136 patients came from 104 families. In 22 families the patient was the only child. In the remaining 82 families we observed 114 patients (54 females and 60 males) who had 198 unaffected sibs. Fifty-nine of these patients were the only cases in the family and 55 came from 23 families in which there were affected sibs. The disease was only recorded in sibships and could not be established with certainty in cousins and relatives. Parents were found to be consanguineous in 6 out of 104 families, i.e. $5 \cdot 8 \%$. In the remaining families consanguinity was denied, but the parents often came from the same or neighbouring villages, which may make some degree of it not unlikely.

The segregation ratio was estimated by Weinberg's sibship method (Table II) and by Lejeune's method $(\mathrm{Li}, 1961)$.
TABLE II

(see Appendix Table A for extended data) WEINBERG'S SIBSHIP METHOD

\begin{tabular}{c|c|c|c|c}
\hline $\begin{array}{c}\text { No. of } \\
\text { Families }\end{array}$ & $\begin{array}{c}\text { No. of } \\
\text { Children } \\
\mathbf{d}\end{array}$ & $\begin{array}{c}\text { No. of } \\
\text { Patients } \\
\mathbf{r}\end{array}$ & $\sum \mathbf{r}(\mathbf{r}-1)$ & $\sum \mathbf{r}(\mathrm{d}-1)$ \\
\hline 82 & 312 & 114 & 98 & 355 \\
\hline
\end{tabular}

according to the formula

$\hat{\mathbf{p}}=\frac{\sum \mathbf{r}(\mathbf{r}-1)}{\sum \mathbf{r}(\mathrm{d}-1)}=\frac{98}{355}=0.276 \pm 0.025(\mathrm{SD})$.

Lejeune's method is based on the a priori method and permits the estimation of the segregation ratio with use of tabulated computations and linear interpolation. For our data the estimate for $\hat{p}$ was $0.225 \pm 0.03$ (Table III).

TABLE III

(see Appendix Table B for extended data) LEJEUNE'S METHOD

\begin{tabular}{c|c|c|c}
\hline $\begin{array}{c}\text { No. of } \\
\text { Families }\end{array}$ & $\begin{array}{c}\text { No. of } \\
\text { Cases Expected }\end{array}$ & $\begin{array}{c}\text { No. of } \\
\text { Cases Observed }\end{array}$ & Variance \\
\hline 82 & 114.041 & 114 & 0.00107 \\
\hline
\end{tabular}

The above methods show the segregation ratio $\hat{\mathrm{p}}$ to be about 0.25 in limb girdle progressive muscular dystrophy. The results indicate that limb girdle dystrophy is a recessive autosomal trait with full penetrance.

In routine studies, the methods described yield satisfactory results. For more complex purposes, one may use the method of maximum likelihood scores described by Bailey (1961), which has been adapted for estimation of the proportion of sporadic cases by Morton and Chung (1959). The proportion of sporadic cases in the total of cases, ' $x$ ' and ' $\hat{p}$ ', may be determined from the distribution of families with one and more affected children. Furthermore, ' $\hat{p}$ ' can be determined independently from the number of affected children in families with more than one.

With probability of ascertainment $\pi=0 \cdot 24$, the estimate was $\hat{p}=0.24 \pm 0.066$, which is not in conflict with the hypothesis of simple recessiveness.* With $\pi=0 \cdot 24$, the result after 8 iterations was $\hat{\mathrm{p}}=$ $0 \cdot 13 \pm 0 \cdot 19$ and $x=0 \cdot 01 \pm 1 \cdot 186$ and subject to no further change. Here, ' $\hat{\mathrm{p}}$ ' was fairly low, though still not in conflict with the hypothesis of recessiveness, whereas the proportion of sporadic cases was virtually nought.

\footnotetext{
* The program for the digital computer was prepared by Mr. J. Pleszczyński, who also made the segregation analysis calculations.
} 
In order to enhance the accuracy of the results, a third stage of estimation was introduced; for $\pi=0.24$ the result was $\hat{\mathrm{p}}=0.24 \pm 0.063$, and $\mathrm{x}=0.35 \pm 0 \cdot 156$.

The proportion of sporadic cases also was determined with the aid of the mean inbreeding coefficient (Table IV).

\section{TABLE IV}

\begin{tabular}{c|c|c|c}
\hline \multicolumn{2}{c|}{$\begin{array}{c}\text { Isolated Cases } \\
\text { (No. of Cases 81) }\end{array}$} & \multicolumn{2}{c}{$\begin{array}{c}\text { Family Cases } \\
\text { (No. of Propositi 26) }\end{array}$} \\
\hline $\begin{array}{c}\text { Pedigree } \\
\text { No. }\end{array}$ & $\begin{array}{c}\text { Inbreeding } \\
\text { Coefficient }\end{array}$ & $\begin{array}{c}\text { Pedigree } \\
\text { No. }\end{array}$ & $\begin{array}{c}\text { Inbreeding } \\
\text { Coefficient }\end{array}$ \\
\hline 31 & $\frac{1}{128}$ & 27 & $\frac{1}{256} \times 2$ \\
74 & $\frac{1}{16}$ & 61 & $\frac{1}{512} \times 2$ \\
84 & $\frac{1}{256}$ & 111 & $\frac{1}{128} \times 2$ \\
\hline
\end{tabular}

For isolated cases the inbreeding coefficient was

$$
\begin{aligned}
F_{1} & =\left(\frac{1}{256}+\frac{1}{16}+\frac{1}{128}\right): 81 \\
& =\frac{19}{256}: 81=\frac{0.074}{81}=0.00091 .
\end{aligned}
$$

For familial cases the inbreeding coefficient was

$$
\begin{aligned}
F_{F} & =\left(\frac{2}{128}+\frac{2}{512}+\frac{2}{256}\right): 26 \\
& =\frac{14}{512}: 26=\frac{0.0273}{26}=0.00105
\end{aligned}
$$

Since data on the frequency of consanguineous marriages in Poland are not available, we assumed for the population the mean inbreeding coefficient for the state of Wisconsin, U.S.A. (Morton, 1961).

We calculated the number $\mathrm{X}$ of sporadic cases among the isolated from the equation

$$
\mathrm{X}=\frac{\mathrm{n}}{\mathrm{n}+\mathrm{N}} \times \frac{\mathrm{F}_{\mathrm{F}}-\mathrm{F}_{1}}{\mathrm{~F}_{\mathrm{F}}-\alpha}
$$

where $\mathrm{n}=$ the number of isolated cases (81),

$\mathrm{N}=$ the number of propositi among family cases (26),

$\mathrm{F}_{\mathrm{F}}=$ the mean inbreeding coefficient for familial cases $(0 \cdot 00105)$,

$F_{1}=$ the mean inbreeding coefficient for the isolated cases $(0 \cdot 00091)$, and

$\alpha=$ the mean inbreeding coefficient for the population $\left(48 \cdot 10^{-6}\right)$.

The figures in parentheses were derived from our material, with the exception of the mean breeding coefficient for the population, which was assumed to be the same as for the state of Wisconsin. Hence

$$
\mathrm{X}=\frac{81}{107} \times \frac{0 \cdot 00105-0.00091}{0.00105-48 \cdot 10^{-6}}=0 \cdot 106 \pm 5.7(\mathrm{SD}) \text {. }
$$

The percentage of sporadic cases among the isolated ones would thus be in the neighbourhood of $10 \%$. Unfortunately, the accuracy of this estimate is slight owing to the large standard deviation.

Relative fitness in patients with limb girdle progressive muscular dystrophy. There were 76 patients aged 25 years or more, who had 55 children. The average number of children was thus $0 \cdot 72$. Sibs of the patients who were unaffected and in the same age category totalled 94 . They had 125 children, which gives an average of 1.33.

The relative fitness, i.e. the ratio of the average number of children of patients to that of the healthy sibs as $0 \cdot 72: 1 \cdot 33=0.54$.

The mutation rate was calculated from the formula $u=(1-f) \times x$, where $f$ is relative fitness and $x$ is the incidence of the defect. Hence $(1-f)=$ $1-0.54=0.46$, which means that $46 \%$ of alleles were eliminated in the given generation.

$$
\mathbf{x}=\frac{\text { births of affected individuals }}{\text { total of births }} \text {. }
$$

The area covered was that of the city and voivodeship of Warsaw in the hope that within it we would be able to assemble data on all patients. In 1946-1957, 15 individuals with limb girdle progressive muscular dystrophy were born against the total of 939,886 other births.* Hence,

$$
\begin{aligned}
& x=\frac{15}{939,886}=0.000016=16 \cdot 10^{-6} \text {, and } \\
& u=0.46 \times 16 \cdot 10^{-6}=7 \cdot 4 \times 10^{-6} .
\end{aligned}
$$

The rate of incidence thus averaged 16 per million births. With the number of patients known for a given area it is possible to estimate prevalence. With the registration of patients in the city and voivodeship of Warsaw assumed to be complete, we had 46 patients in that area against its population of $3,737,000$. Thus there was $1 \cdot 23$ patients for each 100,000 inhabitants.

Facio-scapulo-humeral dystrophy. The patients under observation totalled 29. They came from 12 families. The analysis of pedigrees indicated dominant autosomal inheritance in 7 families. In one family there were 2 affected sibs, and in the remaining 4 the cases were isolated. Both parents were only investigated in 1 of the 5 families in which dominant inheritance could not be demonstrated; only the mother was investigated in 3 families, and in one case the parents of the patient were dead.

Twenty-five of the patients were aged more than 25 years, and 8 of these were single. They had a

* The data of the Polish Statistical Bureau. 
total of 45 children, an average 1.80. Normal sibs of the patients who were in the same age category totalled 16 and had 36 children, an average of $2 \cdot 25$. Consequently, the relative fitness in facio-scapulohumeral progressive muscular dystrophy is $1 \cdot 80: 2 \cdot 25=0 \cdot 80$.

The segregation ratio $\hat{\mathbf{p}}$ was calculated by Weinberg's sibship method (Table V) and by the a priori method (Table VI).

TABLE V

(see Appendix Table $\mathrm{C}$ for extended data)

\begin{tabular}{c|c|c|c|c}
\hline $\begin{array}{c}\text { No. of } \\
\text { Families }\end{array}$ & $\begin{array}{c}\text { No. of } \\
\text { Children }\end{array}$ & $\begin{array}{c}\text { No. of } \\
\text { Patients }\end{array}$ & $\sum \mathbf{r}(\mathbf{r}-1)$ & $\sum \mathbf{r}(\mathrm{d}-1)$ \\
\cline { 2 - 4 } \cline { 3 - 4 } & 63 & 29 & 50 & 103 \\
\hline
\end{tabular}

$\hat{\mathrm{p}}=\frac{\sum \mathrm{r}(\mathrm{r}-1)}{\sum \mathrm{r}(\mathrm{d}-1)}=\frac{50}{103}=0.485 \pm 0 \cdot 13(\mathrm{SD})$.

TABLE VI

(see Appendix Table D for extended data)

\begin{tabular}{c|c|c|c}
\hline \multirow{2}{*}{ No. of Families } & \multicolumn{2}{|c|}{ No. of Patients } & Variance \\
\cline { 2 - 4 } & Expected & Observed & \\
\hline 16 & $34 \cdot 215$ & $\begin{array}{c}29+5 \\
\text { doubtful cases }\end{array}$ & $12 \cdot 367$ \\
\hline
\end{tabular}

$\mathrm{SD}=\sqrt{12 \cdot 36}=3 \cdot 518$.

With $\hat{\mathrm{p}}$ assumed as $0 \cdot 5$, the expected number of patients was $34 \cdot 21 \pm 3 \cdot 5$ (Table VI).

These results are concordant with the actual number of patients (29) and even identical if the 5 doubtful cases are taken into account.

The results obtained for $\hat{p}=0.485 \pm 0.13$ and 0.5 , depending on the method, were in agreement with the theoretical value. So-called anticipation was not observed in the families investigated. The age of parents and children at the onset of the disease was similar (where the disease was recorded in two or three generations).

Since the number of patients under observation was too small, we estimated neither the mutation (which is presumably very low) nor the incidence rates. The prevalence rate was 4 per million.

\section{Discussion}

In our material we had 4 patients with facioscapulo-humeral dystrophy, 12 with the limb girdle type, and 20 with Duchenne's type per million people. Compared with earlier calculations, the figure may be thought too low for the Duchenne type; very likely the relatively brief survival time and early immobilization of the patients make for their incomplete registration.

From the published figures there are from 26 to 59 patients per million (Herndon, 1954; Walton, 1957; Kurland, 1958; Myazaki, 1963; Nogata et al., 1964; Kuroiwa and Myazaki, 1967); this is not strikingly different from our estimates which are probably too low owing to the still imperfect methods of diagnosis, notably in small children, and incomplete registration of the cases, particularly those in rural areas.

Duchenne's progressive muscular dystrophy. The Duchenne gene is sex-linked. The evidence for this is that (1) the disease affects exclusively boys, (2) transmission of the disease by a healthy mother can be proved in some families, and (3) the disease may develop in women with Turner's syndrome (Walton, 1957; Ferrier, Bamatter, and Klein, 1965). The penetrance of the Duchenne gene seems to be complete-the disease becomes manifest in all males who are hemizygous with regard to this gene.

According to our material, the frequency of mutations was $97 \cdot 10^{-6}$ when determined by the less precise direct method, and $46 \cdot 10^{-6}$ by the somewhat more precise indirect method. This approaches the data obtained by other authors who report the frequency of mutations as from $3.8 \times 10^{-5}$ to $9.5 \times 10^{-5}$ (Stephens and Tyler, 1951; Stevenson, 1953; Becker and Lenz, 1955, 1956; Walton, 1956, 1957; Blyth and Pugh, 1959; Morton, Chung, and Peters, 1963; Moser et al., 1964; Rotthauwe and Kowalewski, 1965; Kuroiwa and Miyazaki, 1967).

Haldane (1956) attributes about one-third of the cases to mutations. In our study the calculations of the incidence and morbidity rates were based on data for the city and voivodeship of Warsaw on the assumption that registration was complete for this area. The respective figures obtained were 140 births of affected individuals per million births of boys, and 20 patients for a population of one million. These data are comparable with those reported by Morton et al. (1963) who put the incidence rate at 297 per million births of boys, and the prevalence at 33 per million. Walton's calculations (1956) gave 50 patients per million.

Benign sex-linked progressive muscular dystrophy, i.e. Becker's form. Our material of 2 families with 10 patients was too scant for calculations of the frequency of mutation, incidence rate, and prevalence. Relative fitness in our material was $69 \%$ against $25 \%$ in Rotthauwe and Kowalewski's (1965). The mutation rate, which the latter 
authors estimated as $5 \times 10^{-7}$, would thus be even lower in our material. Moser et al. (1964) reported a frequency of mutations of $1.2 \times 10^{-5}$. These data obviously are greatly lacking in accuracy since the number of observed cases is small, the fertility of patients depends not only on the severity of the disease but also a variety of environmental factors, and the diagnosis of this type of dystrophy is difficult and in isolated cases very unreliable. Finally, Emery and Walton (1967) are now inclined to diagnose three forms of benign Duchenne dystrophy, and each may perhaps occur with a different frequency. To judge by our material, Becker's form is about one-fortieth as frequent as is the acute form of Duchenne's dystrophy.

Limb girdle progressive muscular dystrophy. Determined by Weinberg's method of sibships and Lejeune's method, the segregation ratio was in the neighbourhood of 0.25 in our material, which suggests for the disease a recessive autosomal character with full penetrance in the group investigated. This is inconsistent with the results of the method of segregation analysis, which put the percentage of sporadic cases in the group of isolated cases at 35. The latter figure approaches the data of Morton and Chung (1959) who calculated the proportion of sporadic cases as $x=41 \%$.

The proportion of sporadic cases among the isolated ones also can be estimated with the aid of the mean coefficient of inbreeding, which was $F_{F}=$ $105 \times 10^{-5}$ and $F_{1}=91 \times 10^{-5}$ in our material, and $F_{F}=804 \times 10^{-5}$ and $F_{i}=119 \times 10^{-5}$ in Morton and Chung's. It will be readily noted that the difference between $F_{F}$ and $F_{1}$ is slight in our material, whereas in Morton and Chung's $F_{F}$ is seven times as large as $F_{1}$. This, among other things, probably accounts for the difference in the percentages of sporadic cases, which are $10 \%$ and $41 \%$, respectively. However, as has already been noted in the description of the material, the calculations are burdened with too large an error to carry much weight.

As already emphasized, the isolated cases differ clinically in no way from the familial ones, the mean inbreeding coefficients are very similar, and it is doubtful whether there is adequate reason to assume the existence of sporadic cases in our material.

In 6 families the parents were consanguineous, so the frequency of consanguinity was $5.8 \%$ and lower than reported by Becker (1964), who in his material of 29 sibships found $5(17 \cdot 2 \%)$ that had consanguineous parents. Other authors reported a similarly high proportion of consanguinity among the parents of patients. Becker (1964) reports that only $2 \cdot 1 \%$ of patients came from cities upwards of 10,000 , whereas the distribution of people between urban and rural areas would make it legitimate to expect the percentage of $23.5 \pm 0.042$. He believes that in a considerable proportion of parents from villages there is some blood relationship reaching back to earlier generations. In our material, too, a considerable majority of the patients come from small towns and villages.

The coefficient of relative fitness is $54_{0}^{\circ}$ in our material, and $25 \%$ in that of Morton et al. (1963) and Rotthauwe and Kowalewski's (1965). Very obviously, the lower the coefficient of biological fitness, the higher must be the mutation rate, if the given population is assumed to be in genetical equilibrium. Hence, Morton et al. (1963) give the mutation rate as $3.1 \times 10^{-5}$, and Rotthauwe and Kowalewski (1965) as $3.6 \times 10^{-5}$, whereas in our material it is $7.3 \times 10^{-6}$ per gene per generation. But it needs to be noted that with recessive mutations the calculations of mutation rate are very much open to doubt-the coefficient of biological fitness varies and depends on the milieu from which the patients come. The more primitive this milieu, the higher is the coefficient of biological fitness, and consequently, if a genetical equilibrium is assumed for the population, the lower will be the figure for the mutation rate.

Therefore, though interesting from the theoretical point of view and promoting comparisons of the data reported by different authors, these estimations are very unreliable.

The incidence rate for limb girdle progressive muscular dystrophy was 16 per million births, and prevalence, 12.3 per million of the population. Morton et al. (1963) have calculated the figures as 65 and 20, respectively, and Walton (1957) puts prevalence at 9 per million.

Facio-scapulo-humeral progressive muscular dystrophy. Here the number of patients was small compared with those with the other types of dystrophy but enough for estimations of the genetic ratio, which was calculated by the method of sibships as $\hat{\mathrm{p}}=0 \cdot 48 \pm 0 \cdot 13$. With the a priori method and $\hat{p}$ assumed as 0.5 , the expected number of patients was no different from the actual one. The results indicate autosomal dominant heredity in this group of patients. The family data are not very accurate-not all parents of patients could be examined.

The coefficient of relative fitness was $81 \%$ in our material. According to other authors it is $70 \%$ (Becker and Lenz, 1955, 1956), 73\% (Morton et al., 
1963), and $74 \%$ (Rotthauwe and Kowalewski, 1965). Our figure for the incidence rate was 4 in a population of one million (the same as reported by Morton et al., 1963). Life expectancy was almost equal to the average for the entire population. Presumably, therefore, prevalence also was 4 per million of the population. In view of the high coefficient of relative fitness, the mutation rate would be about $3.0 \times 10^{-7}$ per gene per generation. The published data are somewhat higher and range from $4.7 \times 10^{-7}$ to $4.7 \times 10^{-6}$ (Becker and Lenz, 1955, 1956; Morton et al., 1963; Moser et al., 1964; Rotthauwe and Kowalewski, 1965).

The disease being rather rare, calculations of this kind are of necessity burdened with a large error.

\section{Summary}

380 Patients with progressive muscular dystrophy coming from 296 families have been studied. On the basis of a study of 215 patients with the Duchenne type of progressive muscular dystrophy, the mutation rate in this disease has been estimated as $46 \cdot 10^{-6}$ per gene per generation. The incidence rate was estimated as 140 per million, the prevalence 19.5 per million population. Only 2 families with the benign X-linked progressive muscular dystrophy have been observed. Relative fitness in this group was estimated as $0 \cdot 70$.

In a group of 136 patients with the limb girdle type of progressive muscular dystrophy, the genetic ratio was estimated by Weinberg's sibship and proband methods and by Lejeune's method as $0 \cdot 27$, $0 \cdot 14,0 \cdot 22$, respectively. Mutation rate in this form was estimated as $7 \cdot 3 \times 10^{-6}$ per gene per generation.

The proportion of sporadic cases estimated by segregation analysis was $0 \cdot 35$, by inbreeding analysis $-0 \cdot 10$. Relative fitness was estimated as $0 \cdot 54$, incidence rate as 16 per million, prevalence rate $12 \cdot 3$ per million population.

Twenty-nine patients with facio-scapulo-humeral progressive muscular dystrophy were observed. The genetic ratio by Weinberg's sibship method and by $a$ priori method was 0.48 and 0.5 , respectively. Relative fitness was estimated $0 \cdot 80$, prevalence rate as 4 per million population.

\section{REFERENCES}

Bailey, N. T. J. (1961). Introduction to the Mathematical Theory of Genetic Linkage. Clarendon Press, Oxford.
Becker, P. E. (1964). Myopathien. In Humangenetik, Band III/1, 411-550. Ed. by P. E. Becker. G. Thieme, Stuttgart.

- (1962). Two new families of benign sex-linked recessive muscular dystrophy. Revue Canadienne de Biologie, 21, 511-566.

- and Lenz, F. (1955). Zur Schätzung der Mutationsrate der Muskeldystrophien. Zeitschrift für menschliche Verebungs- und Konstitutions-lehre, 33, 42-56.

- and - (1956). Zur Schätzung der Mutationsrate der Muskeldystrophien: Nachtrag. Zeitschrift für menschliche Vererbungs- und Konstitutions-lehre, 33, 463-464.

Blyth, H. and Pugh, R. J. (1959). Muscular dystrophy in childhood. The genetic aspect. Annals of Human Genetics, 23, 127163.

Emery, A. E. H. and Walton, J. N. (1967). The genetics of muscular dystrophy. In Progress in Medical Genetics, 5, 116-145.

Ferrier, P., Bamatter, F., and Klein, D. (1965). Muscular dystrophy (Duchenne) in a girl with Turner's syndrome. Fournal of Medical Genetics, 2, 38-46.

Haldane, J. B. S. (1935). The rate of spontaneous mutation of a human gene. Fournal of Genetics, 31, 317-326.

- (1956). Mutation in the sex-linked recessive type of muscular dystrophy. A possible sex difference. Annals of Human Genetics, 20, 344-347.

Herndon, C. N. (1954). Three North Carolina surveys-Muscular dystrophy survey. American fournal of Human Genetics, 6, 65-69.

Kurland, L. T. (1958). Descriptive epidemiology of selected neurologic and myopathic disorders with particular reference to a survey in Rochester, Minnesota. Fournal of Chronic Diseases, 8, 378-418.

Kuroiwa, Y. and Miyazaki, T. (1967). Epidemiological study of myopathy in Japan. In Exploratory Concepts in Muscular Dystrophy and Related Disorders, pp. 98-102. Ed. by A. T. Milhorat. Excerpta Medica Foundation, Amsterdam.

Li, C. (1961). Human Genetics. McGraw-Hill, New York.

Morton, N. E. (1961). Morbidity of children from consanguineous marriages. Progress in Medical Genetics, 1, 261-291.

- and Chung, C. S. (1959). Formal genetics of muscular dystrophy. American fournal of Human Genetics, 11, 360-379.

$\longrightarrow,-$, and Peters, H. A. (1963). Genetics of muscular dystrophy. In Muscular Dystrophy in Man and Animals. Ed. by G. H. Bourne and M. N. Golarz. pp. 323-365. S. Karger, Basel.

Moser, H., Wiesmann, U., Richterich, R., and Rossi, E. (1964). Progressive muscular dystrophy. VI Incidence, clinical aspects and genetics of the Duchenne type. Schweizerische medizinische Wochenschrift, 94, 1610-1621.

Nogata, Y., Kato, Y., Jida, M., and Sobue, I. (1964). An epidemiologic study on myopathy in the city of Nagaya (Japanese). Clinical Neurology, 4, 8, 478 .

Rotthauwe, H. W. and Kowalewski, S. (1965). Klinische und biochemische Untersuchungen bei Myopathien. II. Die Bedeutung der Serum-Kreatin-Phosphokinase und der Serum-Aldolase für die Identifizierung von Heterozygoten der recessiv $\mathbf{x}$-chromosomalen Formen der progressiven Muskeldystrophie 'Typ III a und b'. Klinische Wochenschrift, 43, 150-158.

Stephens, F. E. and Tyler, F. H. (1951). Studies in disorders of muscle. $V$. The inheritanee of childhood progressive muscular dystrophy in 33 kindreds. American fournal of Human Genetics, 3, 111-125.

Stevenson, A. C. (1953). Muscular dystrophy in Northern Ireland. I. An account of the condition in fifty-one families. Annals of Eugenics, 18, 50-93.

Walton, J. N. (1956). The inheritance of muscular dystrophy: further observations. Annals of Human Genetics, 21, 40-58. (1957). The inheritance of muscular dystrophy. Acta Genetica et Statistica Medica, 7, 318-320. 
Appendix

TABLE A

GENETIC ANALYSIS OF 82 FAMILIES WITH LIMB GIRDLE PROGRESSIVE MUSCULAR DYSTROPHY (WEINBERG'S SIBSHIP METHOD)

\begin{tabular}{c|c|c|c|c|c}
\hline $\begin{array}{c}\text { Size of } \\
\text { Sibship }\end{array}$ & $\begin{array}{c}\text { No. of } \\
\text { Sibships } \\
\text { s }\end{array}$ & $\begin{array}{c}\text { No. of } \\
\text { Sibs } \\
\mathrm{d}\end{array}$ & $\begin{array}{c}\text { No. of } \\
\text { Affected } \\
\mathbf{r}\end{array}$ & $\sum \mathbf{r}(\mathbf{r}-1)$ & $\sum \mathbf{r}(\mathbf{d}-1)$ \\
\hline 2 & 19 & 38 & 21 & 4 & 21 \\
3 & 20 & 60 & 27 & 16 & 54 \\
4 & 20 & 80 & 29 & 24 & 87 \\
5 & 15 & 75 & 19 & 8 & 76 \\
6 & 4 & 24 & 9 & 30 & 45 \\
7 & 2 & 14 & 3 & 2 & 18 \\
9 & 1 & 9 & 4 & 12 & 32 \\
12 & 1 & 12 & 2 & 2 & 22 \\
\hline Total & 82 & 312 & 114 & 98 & 355 \\
\hline
\end{tabular}

TABLE C

GENETIC ANALYSIS OF 16 FAMILIES WITH FACIO-SCAPULO-HUMERAL PROGRESSIVE MUSCULAR DYSTROPHY (WEINBERG'S SIBSHIP METHOD)

\begin{tabular}{c|c|c|c|c|c}
\hline $\begin{array}{c}\text { Size of } \\
\text { Sibship }\end{array}$ & $\begin{array}{c}\text { No. of } \\
\text { Sibships } \\
\text { s }\end{array}$ & $\begin{array}{c}\text { No. of } \\
\text { Sibs } \\
\mathrm{d}\end{array}$ & $\begin{array}{c}\text { No. of } \\
\text { Affected } \\
\mathrm{r}\end{array}$ & $\sum \mathbf{r}(\mathbf{r}-1)$ & $\sum \mathbf{r}(\mathrm{d}-1)$ \\
\cline { 1 - 5 } 2 & 4 & 8 & 4 & 0 & \\
3 & 2 & 6 & 4 & 6 & 8 \\
4 & 5 & 20 & 6 & 2 & 18 \\
5 & 2 & 10 & 4 & 4 & 16 \\
6 & 2 & 12 & 9 & 36 & 45 \\
7 & 1 & 7 & 2 & 2 & 12 \\
\hline Total & 16 & 63 & 29 & 50 & 103 \\
\hline
\end{tabular}

TABLE B

ANALYSIS WITH LEJEUNE'S METHOD OF 82 SIBSHIPS WITH LIMB GIRDLE PROGRESSIVE MUSCULAR DYSTROPHY ( $\hat{\mathbf{p}}=\mathbf{0} \cdot 225$ ASSUMED)

\begin{tabular}{c|c|r|r|r}
\hline $\begin{array}{c}\text { Size of } \\
\text { Sibship }\end{array}$ & \multirow{2}{*}{$\begin{array}{c}\text { No. of } \\
\text { Sibships }\end{array}$} & \multicolumn{2}{|c|}{ No. of Affected } & \multirow{2}{*}{ Variance } \\
\cline { 3 - 4 } & & Expected & Observed & \\
\hline 2 & 19 & 21.413 & 21 & $69 \cdot 160$ \\
3 & 20 & $25 \cdot 260$ & 27 & $155 \cdot 480$ \\
4 & 20 & $28 \cdot 160$ & 29 & 247.340 \\
5 & 15 & $23 \cdot 445$ & 19 & $260 \cdot 700$ \\
6 & 4 & 6.892 & 9 & 91.044 \\
7 & 2 & 3.786 & 3 & 56.916 \\
9 & 1 & $2 \cdot 252$ & 4 & $40 \cdot 578$ \\
12 & 1 & 2.833 & 2 & 59.815 \\
\hline Total & 82 & 114.041 & 114 & 981.033 \\
\hline
\end{tabular}

TABLE D

ANALYSIS WITH $A$ PRIORI METHOD OF 16 FAMILIES WITH FACIO-SCAPULO-HUMERAL TYPE OF PROGRESSIVE MUSCULAR DYSTROPHY ( $\hat{\mathrm{p}}=0.5$ ASSUMED)

\begin{tabular}{c|c|c|c|c}
\hline \multirow{2}{*}{$\begin{array}{c}\text { Size of } \\
\text { Sibship }\end{array}$} & $\begin{array}{c}\text { No. of } \\
\text { Sibships }\end{array}$ & \multicolumn{2}{|c|}{ No. of Affected } & \multirow{2}{*}{ Variance } \\
\cline { 3 - 5 } & Expected & Observed & \\
\hline 2 & 4 & $5 \cdot 332$ & 4 & 0.888 \\
3 & 2 & 3.430 & 4 & 0.980 \\
4 & 5 & $10 \cdot 670$ & 6 & 3.910 \\
5 & 2 & $5 \cdot 162$ & 4 & 2.164 \\
6 & 2 & 6.094 & 9 & 2.758 \\
7 & 1 & 3.527 & 2 & 1.667 \\
\hline Total & 16 & 34.215 & 29 & 12.367 \\
\hline
\end{tabular}

